\title{
Thrombophilia: the dermatological clinical spectrum
}

\author{
Paulo Ricardo Criado ${ }^{1 *}$, Gleison Vieira Duarte ${ }^{2}$, Lidia Salles Magalhães ${ }^{2}$ and Jozélio Freire de Carvalho ${ }^{2}$ \\ ${ }^{1}$ Department of Dermatology, Universidade de São Paulo, Brazil \\ ${ }^{2}$ Rheumatology, Universidade Federal da Bahia, Brazil
}

\begin{abstract}
The aim of this article is to review the hypercoagulable states (thrombophilia) most commonly encountered by dermatologists, as well as their cutaneous signs, including livedo racemosa, cutaneous necrosis, digital ischemia and ulcerations, reticulated purpura, leg ulcers, and other skin conditions. Recognizing these cutaneous signs is the first step to proper treatment. Our aim is to describe which tests are indicated, and when, in these clinical settings.
\end{abstract}

\section{Introduction}

The possible causes of vascular occlusion can be divided into three large groups: (i) abnormalities of the vascular wall, (ii) changes in blood flow, and (iii) hypercoagulation of the blood [1]. The term thrombophilia was introduced in 1965 by Egeberg [2] and is currently used to describe conditions resulting from hereditary (or primary) and/or acquired hyper-coagulation of the blood that increase the predisposition to thromboembolic events [3]. Various risk factors, whether genetic or acquired, make up the pathogenesis of thrombosis in both arteries and veins [3]. Some individuals develop recurring thromboses despite preventative measures or develop thromboses in unusual locations [46] and can exhibit a state of hidden hypercoagulability [4].

With regard to acquired thrombophilia, the following conditions are observed: cryoglobulinemia, thrombotic thrombocytopenic purpura, myeloproliferative syndromes, nephrotic syndrome, hypercoagulability associated with cancer, and antiphospholipid syndrome [1]. Table 1 shows the hereditary and acquired risk factors most related to venous thrombosis [3].

Risk factors for venous thromboembolism (VTE) (advanced age, prolonged immobilization, surgery, fractures, use of hormonal contraceptives, pregnancy, puerperium, neoplasms, and antiphospholipid syndrome [5]) differ from those for arterial thrombotic disease (arterial hypertension, smoking, dyslipidemia, and diabetes mellitus) [5]. In Western countries, the incidence of VTE per year is approximately 1 in every 1,000 individuals $[7,8]$.

Screening for states of hypercoagulability in the general population is not practical from either a clinical or economic point of view [4].

The scope of this article is to review the states of hypercoagulability (thrombophilia) most likely to be encountered by the dermatologist, their clinical manifestations, which exams are indicated in these situations, and when such exams are indicated.

\section{Hereditary thrombophilia}

Since the 1950s, the description of states of "hypercoagulability" a group of abnormalities associated with hyperactivity of the clotting system and/or the occurrence of thrombotic phenomena - changed the view of VTE [9].
Hereditary thrombophilia can be classified into three large groups according to the pathogenic mechanism [1]:

(i) Reduction of anticoagulant capacity: There are two systems capable of blocking the clotting cascade and preventing the development of a massive and uncontrollable thrombosis: natural anticoagulants (antithrombin III, protein $\mathrm{C}$, and protein S) and fibrinolysis (plasminogen-plasmin system). A congenital deficit in any one of these components constitutes a possible cause of primary thrombophilia.

(ii) Increase in coagulant capacity: Within this group is included the following:

a. Resistance to activated protein C. In approximately 90 to $95 \%$ of cases, resistance to activated protein $\mathrm{C}$ is due to a unique mutation in clotting factor $\mathrm{V}$ known as factor $\mathrm{V}$ Leiden. There are other causes of resistance to activated protein $\mathrm{C}$ that are not due to factor V Leiden such as antiphospholipid syndrome and other, rarer mutations.

b. Mutation of the prothrombin G20210A gene.

c. Elevated levels of clotting factors VIII, IX, and XI.

d. Dysfibrinogenemia.

(iii) Other conditions: This group primarily includes hyperhomocysteinemia. Levels of homocysteine can be elevated due to acquired causes (chronic renal insufficiency, hypothyroidism, and deficiencies in folic acid or vitamin $B_{12}$ ) and to genetic factors. Among the causes of hyper-homocysteinemia, the most frequent is mutation of the methylenetetrahydrofolate reductase gene (MTHFR) (mutation C677T).

Inherited deficiencies in antithrombin (AT), protein C (PC), and its co-factor protein S (PS) were the first identified causes of thrombophilia [10]. Over the last decade, two common genetic polymorphisms were

Correspondence to: Paulo Ricardo Criado, Rua Carneiro Leão 33, Vila Scarpelli - Santo André - São Paulo - Brazil, CEP: 09050-430, E-mail: prcriado@uol.com.br

Key words: thrombophilia, factor $V$, purpura, leg ulcer, livedo racemosa, thrombosis

Received: March 20, 2016; Accepted: April 14, 2016; Published: April 18, 2016 
Table 1. Genetic (hereditary) and acquired risk factors for thrombotic events

\begin{tabular}{|c|c|}
\hline A. & Causes of inherited thrombophilias: \\
\hline 1. & Antithrombin Deficiency \\
\hline 2. & Protein C Deficiency \\
\hline 3. & Protein S Deficiency \\
\hline 4. & Mutation of Factor V (Leiden) (resistance to activated protein C) \\
\hline 5. & Mutation of Factor II (Prothrombin) \\
\hline 6. & Hyperhomocysteinemia \\
\hline 7. & Altered plasma levels of coagulation factors \\
\hline a. & Elevated levels of factor VIII \\
\hline b. & Elevated levels of fibrinogen \\
\hline c. & Elevated levels of factor IX \\
\hline d. & Elevated levels of factor XI \\
\hline 8. & Mutation of factor XIII \\
\hline 9. & Increase of inhibitor of activator of tissue plasminogen \\
\hline 10. & Decrease of activator of tissue plasminogen \\
\hline 11. & Abnormal Plasminogen \\
\hline 12. & Cryoglobulnemia \\
\hline 13. & Deficiency of Heparin Co-factor II \\
\hline 14. & Rigid platelet syndrome \\
\hline 15. & Elevated levels of Lipoprotein a \\
\hline B. & Causes of acquired thrombophilias: \\
\hline 1. & Antiphospholipid Antibody Syndrome \\
\hline 2. & Paroxysmal Nocturnal Hemoglobinuria \\
\hline 3. & Myeloproliferative diseases \\
\hline 4. & Pregnancy and puerperium \\
\hline 5. & Neoplasms \\
\hline 6. & Nephrotic Syndrome \\
\hline 7. & Hyperviscosity (including cryoglobulinemia) \\
\hline & Drug-related: \\
\hline \multicolumn{2}{|c|}{ - hormone replacement therapy } \\
\hline \multicolumn{2}{|c|}{ - oral contraceptives } \\
\hline \multicolumn{2}{|c|}{ - tamoxifen/raloxifene } \\
\hline \multicolumn{2}{|c|}{ - chemotherapy/thalidomide } \\
\hline \multicolumn{2}{|c|}{ - heparin-induced thrombocytopenia } \\
\hline \multicolumn{2}{|c|}{ - coumarin-induced skin necrosis } \\
\hline 9. & Trauma and Surgeries \\
\hline 10. & Prolonged immobilization \\
\hline 11. & Policythemia Vera \\
\hline 12. & Vasculitis \\
\hline 13. & Central venous catheter \\
\hline 14. & Long trips \\
\hline 15. & Inflammatory bowel disease \\
\hline 16. & Hyperhomocysteinemia \\
\hline 17. & Resistance to protein $\mathrm{C}$ unrelated to Leiden Factor $\mathrm{V}$ \\
\hline
\end{tabular}

recognized as causes of hypercoagulability: mutant factor $\mathrm{V}$ and factor V G1691A (factor V Leiden), which make factor V resistant to the anticoagulant action of protein $C$ [10], and mutation of the prothrombin gene (prothrombin G20210A), which is associated with an increase in circulating levels of prothrombin [11].

In contrast to monogenic inherited diseases in which a single gene leads to disease, multigenic diseases stem from different mutations in distinct genes [5]. Multigenic diseases can also result from the interaction of a heterogeneous set of events, which are genetic in origin, with environmental events [5]. Therefore, in addition to being multigenic, the factors are generally multifactorial [5]. Thus, the concept of multigenic diseases is applicable to various conditions, including VTE [5].

Deficiencies in natural clotting inhibitors (AT, PC, and PS) are rare and detected in less than $1 \%$ of the general population and in less than $10 \%$ of those who do not demonstrate VTE (Table 2) [10]. Among carriers of these deficiencies, the risk of VTE is 5 to 8 times greater than for the general population [10]. The first thrombolytic event usually occurs before 45 years of age [10].

From a practical point of view, the principal inherited thrombophilias may be divided into two groups [1].

(i) High prevalence thrombophilias with low thrombogenicity: resistance to activated protein $\mathrm{C}$, mutation of the gene for prothrombin (G20210A), hyperhomocysteinemia, or increased levels of clotting factors VIII or XI.

(ii) Low prevalence thrombophilias, with high thrombogenicity: deficiency in antithrombin III, protein $\mathrm{C}$, or protein $\mathrm{S}$.

\section{Factor V leiden}

Factor V Leiden (FVL), also known as $\mathrm{FVR}^{506} \mathrm{Q}$ or $\mathrm{FV}: \mathrm{Q}^{506}$ accounts for $95 \%$ of cases that have a single point mutation in the factor V clotting factor [5,10]. Position 506 is the site where activated protein $\mathrm{C}$ cleaves $\mathrm{FVa}$ [5]. This mutation makes activated factor $\mathrm{V}$ (FVa) extremely resistant to the proteolytic activity of protein $\mathrm{C}$, which results in resistance to protein C (APC resistance or APC-R) [10]. The heterozygous mutation of FVL increases the risk for VTE 3 to 8 fold whereas the homozygous mutation increases the risk 50 to 100 fold [5]. FVL is found in 10 to $60 \%$ of VTE cases [12].

Currently, APC-R is routinely tested for when investigating VTE using the assay based on TTPA and plasma deficient in factor V to dilute the test samples. This test can reliably distinguish between heterozygous and homozygous carriers and individuals who are not

Table 2. Epidemiology of inherited thrombophilias and their association with venous thromboembolism (VTE).

\begin{tabular}{|c|c|c|c|c|c|c|}
\hline Inheritance of thrombophilia & $\begin{array}{c}\text { General Caucasian } \\
\text { population } \\
(\% \text { of carriers })\end{array}$ & $\begin{array}{l}\text { Patients with non- } \\
\text { selected VTE } \\
\text { (\% of carriers) }\end{array}$ & $\begin{array}{l}\text { Patients with } \\
\text { selected VTE } \\
\text { (\% of carriers) }\end{array}$ & $\begin{array}{l}\text { Relative risk of VTE } \\
\text { (Case-control studies) }\end{array}$ & $\begin{array}{c}\text { Relative risk of VTE } \\
\text { (family studies) }\end{array}$ & $\begin{array}{c}\text { Annual incidence of } \\
\text { VTE (\%) }\end{array}$ \\
\hline AT deficiency & 0.02 to 0.16 & 1.9 & 4.3 & 5 & 5 to 8 & 1 to 2 \\
\hline PC deficiency & 0.2 to 0.4 & 3.7 & 4.8 & 6.5 & 5 to 8 & 1 to 2 \\
\hline PS deficiency & $(-)$ & 2.3 & 4.3 & 1.7 & 5 to 8 & 1 to 2 \\
\hline Factor V Leiden & 4.8 & 18.8 & 18 & $\begin{array}{c}7 \text { for (heterozygotes) } \\
40 \text { to } 80 \text { for (homozygotes) }\end{array}$ & 2 to 4 & 0.19 to 0.67 \\
\hline $\begin{array}{l}\text { Mutant Prothrombin } \\
\text { (PT G20210A) }\end{array}$ & 2,0 & 7.1 & 7.3 & 2 to 3 & 2 & 0.13 \\
\hline Factor V Leiden + PT G20210A & 0.01 (expected) & $(-)$ & 2.2 & 20 & 6 & 0.57 \\
\hline Hyper-homocysteinemia & 5 & 13 to 25 & 10 to 25 & 2,5 & $(-)$ & $(-)$ \\
\hline MTHFR 677 TT & 13.7 & $(-)$ & 13.9 & 1 & $(-)$ & $(-)$ \\
\hline
\end{tabular}

Legend: AT, antithrombin; PC, protein C; PS, protein S; MTFFR, methylenetetrahydrofolate reductase. Adapted from De Stefano et al. [11] 
carriers [5]. Alternatively, molecular analysis techniques, such as amplification by polymerase chain reaction (PCR), can be used [5].

If a patient with FVL presents recurring thromboses, prolonged anticoagulation with warfarin is required to maintain the International Normalized Ratio (INR) between 2.0 and 3.0 [4].

\section{Mutation G20210A of clotting factor II (Prothrombin)}

Described about 10 years as the transition from guanine to adenosine in nucleotide 20210 of the gene for clotting factor II [12], this mutation is associated with hyperprothrombinemia and an increase in the formation of thrombin and in the risk of VTE [13]. The mutation occurs in 1 to $3 \%$ of the general population and in 6 to $18 \%$ of patients with VTE and is the second most common genetic abnormality for thrombophilia $[5,10]$. This condition is diagnosed by gene analysis techniques, similar to FVL [5].

Ideal management for patients with the prothrombin mutation has not yet been established by consensus [4]. It is likely to involve long-term anticoagulation with warfarin in those with thrombosis at an early age or recurring thrombosis [4]. Kearon et al. [14] suggest that only individuals with an exogenous risk factor (for example, prolonged immobilization) should receive anticoagulants.

\section{Antithrombin deficiency}

Antithrombin (AT), previously called antithrombin III, is a natural anti-clotting factor that binds to heparan sulfate in endothelial cells and inactivates thrombin [4]. It also inhibits activated factor X and, to a lesser degree, factors IX, XI, and XII [15]. The prevalence of inherited prothrombin deficiency is 1 in 5,000 individuals [4]. Until now, approximately 100 mutations in the AT gene that lead to clinically relevant AT deficiency syndrome have been identified [4,5]. In type I AT deficiency syndrome, there is a functional and quantitative reduction of AT [4]. In type II AT deficiency syndrome, the production of AT is relatively normal whereas the activity of AT is reduced [4].

The risk of thrombosis increases when the functional activity of AT is reduced to less than $80 \%$ of normal levels [16]. The level of AT in heterozygotes is generally between 40 to $70 \%$ of normal levels [4]. Homozygosity is generally lethal to the embryo [4]. In heterozygotic AT deficiency, the risk of VTE is increased tenfold [5]. VTE resulting from AT deficiency is unusual prior to age twenty, with a plateau for incidence around forty, and occurs earlier in women than in men [4].

Patients with acute thrombotic complications due to AT deficiency are treated with heparin combined with exogenous AT [4]. The goal is to maintain TTPA levels at 1.5 to 2.0 times the normal values [4]. Treatment with warfarin, which can increase basal AT levels, is recommended for patients who suffer a thrombotic event [4].

\section{Deficiency of proteins $C$ and $S$}

Protein $\mathrm{C}$ and protein $\mathrm{S}$ are endogenous vitamin K-dependent anticoagulant proteins synthesized in the liver [4]. Their levels are reduced in patients with liver insufficiency, chronic renal insufficiency, deficiency of vitamin $\mathrm{K}$, and disseminated intravascular coagulation and during acute episodes of thrombosis [4]. The protein C pathway is the dominant endogenous anticoagulant pathway [4]. PCa quickly inactivates activated clotting factors V and VIII [4]. The activity of both factors can be reduced to $20 \%$ of normal levels within 3 minutes, and all of their activity is eliminated in 5 minutes [17]. PCa also reduces the activity of the inhibitor of the activator of tissue plasminogen (PAI-I), thereby increasing the fibrinolytic potential by reducing inhibition of the conversion of plasmin into plasminogen [4].

Congenital PC deficiency is transmitted as a dominant autosomal trait, with a prevalence of 1:200 to 1:300 [4]. Type I PC deficiency consists of quantitative and functional reduction of PC whereas type II PC deficiency consists only of functional reduction of protein C [14]. Levels of PC less than $2.0 \mathrm{mg} / \mathrm{L}$ are prevalent in $3.2 \%$ of the population [4].

Protein S (PS) is a co-factor of PC that activates PCa [4]. PS considerably increases the rate of inactivation of FVa by $\mathrm{PCa}$ in the presence of phospholipids but does not in itself have endogenous anticoagulant or fibrinolytic activity [4]. It is inherited with variable penetration, and homozygosity is associated with fulminating neonatal purpura, characterized by thrombosis of microcirculation, with serious effects on the skin [19].

Deficiencies in AT, PC, and PS are diagnosed by measuring the plasma levels of the respective proteins using functional or immunological methods [5].

There is little evidence to support the benefits of prophylactic anticoagulation in patients with PC or PS deficiency [4]. However, after a thrombotic episode, treatment with heparin should be instituted followed by the introduction of warfarin to adjust the INR between 2.0 and 3.0 [4].

Deficiencies in AT, PC, and PS account for only 5 to $15 \%$ of all VTE cases in various populations [5].

\section{Deficiency of heparin cofactor II}

Heparin cofactor II directly inhibits heparin production in the liver [4]. Deficiency of this cofactor is rare and is transmitted as a dominant autosomal trait [4]. Heparin increases the inactivation rate of thrombin through its cofactor II [4]. A greater than 50\% reduction of heparin cofactor II is associated with an increase in the risk of thrombosis [21].

\section{Hyper-homocysteinemia}

Elevated concentrations of homocysteine (hyper-homocysteinemia, HHC) are involved in early vascular disease [4]. HHC is present in 25 to $32 \%$ of patients with early peripheral occlusive arterial disease [4]. Moderate HHC is a risk factor for arterial and venous occlusions [10]. Genetic factors can interact with acquired factors (low intake of pyridoxine, cobalamin, and folate) to produce moderate HHC [10]. Homozygous carriers can develop $\mathrm{HHC}$, especially in the presence of low levels of folate [10]. In Caucasians, the prevalence of the homozygous genotype (TT) is $13.7 \%$, which is similar to that in patients with VTE, suggesting that studying this genotype has no clinical use per se $[10]$.

Hyper-homocysteinemia is treated with folate supplements (1 to 3 $\mathrm{mg}$ /day) and vitamins $\mathrm{B}_{6}$ and $\mathrm{B}_{12}$ if necessary [4].

\section{Combined inherited defects}

The risk of a first thrombotic event increases in the presence of combined genetic defects [10]. The combination of moderate HHC and FVL or mutation of the prothrombin gene increases the risk of VTE 20 to 50 times [10].

\section{Additional plasma abnormalities associated with increased risk of venous thrombosis}

An increase in the levels of circulating fibrinogen, lipoprotein, F VIII, F IX, or FXI elevates the risk for VTE by 2 to 4 fold. It has 
been recently demonstrated that an increase in the levels of thrombinactivated fibrinolysis inhibitor (TAFI) increases the risk for VTE by 1.7 fold [10].

\section{Acquired thrombophilias}

\section{Antiphospholipid antibody syndrome (AAS)}

AAS is an auto-immune acquired thrombophilia characterized by the presence of antiphospholipid antibodies (AA), thrombotic disorders, and/or recurring loss of fetuses [22]. AAs are immunoglobulins (Ig), especially $\operatorname{IgG}, \operatorname{IgM}$, and $\operatorname{IgA}$, that bind to complexes formed by anionic phospholipids, primarily cardiolipin, and plasma proteins [22], primarily $\beta$-2-glicoprotein I ( $\beta_{2}$ GP-I) and prothrombin [22]. Some of these antibodies can bind directly to phospholipids without the need to interact with plasma proteins, generally in situations involving ingestion of drugs, infections, and neoplasms but are generally not associated with thrombotic disease [22].

AAs can be detected in the laboratory by a) interfering with in vitro clotting tests dependent on phospholipids, a phenomenon called lupus anticoagulant (LA) or b) by the immunoenzymatic assay method (ELISA) [22]. The latter method detects antibodies against the plasmaphosopholipid protein complex through the use of a phospholipid as an antigen (especially cardiolipin), anticardiolipin antibodies (ACA), or purified protein extracts as an antigen $\left(\beta_{2}\right.$ GP-I) (anti- $\beta_{2}$ GP-I antibodies) [22].

The spectrum of thrombotic manifestations of AAS is broad [3]. All age brackets are affected. Approximately $70 \%$ of thromboses occur in veins, whereas $30 \%$ occur in arteries [3]. Peripheral and visceral occlusions may occur, and cerebrovascular complications are frequent [1]. Dermatological manifestations are broad and are classified as thrombotic or non-thrombotic [22-25]. Thrombotic manifestations consist of necrotic ulcers of the livedoid vasculopathy or Degos disease, extensive necrotic ulcers of the gangrenous pyoderma, periungual ulcerations, necrotizing purpura, superficial venous thrombosis of the thrombophlebitis type, digital gangrene, multiple linear subungual hemorrhages, and disseminated superficial cutaneous necrosis or retiform purpura. Non-thrombotic manifestations consist of livedo reticularis, livedo racemosa, acrocyanosis, primary anetoderma, blue fingers syndrome, chronic pigmentous purpura, and chronic urticaria. Cutaneous involvement in acetylsalicylic is common [22,26,27]. Histopathological examination can reveal thrombosis of the veins, arterioles, and small to medium size arteries in the skin (dermis and subcutaneous tissue) without an inflammatory component in the vessel wall [22].

The criteria for diagnosing AAS were established at the Eighth International Congress on Antiphospholipid Antibodies, which took place in Sapporo, Japan in 1998 and were later revised at the Eleventh Congress in Sydney, Australia in 2004. However, dermatological findings are not among the clinical criteria [28].

Dermatological manifestations can aid in diagnosis but cannot always be effectively treated [22]. For example, livedo reticularis does not improve despite anticoagulant treatment [22]. Extensive cutaneous necrosis and digital gangrene require an oral anticoagulation (warfarin) and maintaining the INR between 2 and 3 [22]. Pseudovasculites (purpura lesions, small papules, erythematous and violaceous nodules, and focal skin necrosis) and livedoid vasculopathy may respond to acetylsalicylic acid (100 mg/day, orally) or anti-platelet agents [22]. Anticoagulation should be considered for serious or recurring manifestations [22].

\section{Paroxysmal nocturnal hemoglobinuria (PNH)}

$\mathrm{PNH}$ is an acquired and rare clonal disease [3] with an incidence of 2 to 6 cases per 1 million individuals/year. PNH can occur at any age but occurs most frequently at approximately 35 years of age [3]. It manifests clinically as intravascular hemolysis accompanied by hemoglobinuria, pancytopenia, and thrombotic events [3]. Extensive purpura is a frequent finding. An acquired mutation in the PIG-A gene (phosphatidyl inositol glycan complement group A) is responsible for the disease. PNH is diagnosed using flow cytometry [3].

\section{Myeloproliferative diseases}

Myeloproliferative diseases consist of a group of chronic diseases involved in clonal proliferation of the bone marrow (BM) progenitor cells [3]. Thrombotic manifestations can occur in myelofibrosis (agnogenic myeloid metaplasia), principally in the portal system, when there is thrombocytosis after splenectomy [3]. Polycytemia vera (PV) and essential thrombocytemia (ET) are more commonly associated with venous or arterial thrombosis [3]. The majority of thrombotic events take place either at presentation or in the two years preceding diagnosis [3].

Erythromelalgia occurs with greater frequency in ET and is characterized by erythema and pain in the extremities and may evolve to serious ischemia and even to peripheral gangrene [3]. The response to acetylsalicylic acid is excellent [3].

\section{Malignant neoplasms}

Thromboembolic events take place in approximately 10 to $15 \%$ of patients with malignant neoplasms and are the second leading cause of death for these patients [3]. The most frequently associated neoplasms are those of the lungs, pancreas, stomach, intestine, ovaries, and prostate [3].

The incidence of neoplasms is greater in patients with venous thrombosis with no defined cause. They can affect both arteries and veins. Individuals with recurring VTE should be tested for neoplasms [3].

The mechanisms for thrombosis in neoplasms have not yet been fully elucidated [3].

Patients with neoplasms present a high risk for post-operative VTE. Prophylaxis with heparin (non-fractionated or low molecular weight) is indicated if surgery is necessary and should be maintained for 2 to 4 weeks after the operation [3].

\section{Pregnancy and puerperium}

Pregnancy results in a 5 to 6 fold greater risk of VTE, which is even greater puerperium (up to six weeks after birth) $[3,29]$. The risk of deep vein thrombosis (DVT) increases during pregnancy, with almost $50 \%$ of events occurring in the third trimester [29].

\section{Drugs related to the risk of thrombosis}

Hormone therapy [hormonal contraceptives (HC), hormone replacement, and tamoxifen], chemotherapy, and thalidomide have been associated with VTE [29]. The annual incidence of DVT in women using $\mathrm{HC}$ is 2 to 3 cases per 100,000 compared to 0.8 cases per 100,000 women who do not use HC [29]. The risk of VTE is greater with HC that contain higher estrogen levels and for those with third generation progestins (desogestrel or gestodene) [29]. These hormones reduce AT and PS levels and increase the levels of pro-coagulant factors, resulting in hypercoagulability [28]. The Women's Health Initiative (WHI) 
showed that hormone replacement therapy doubles the risk of VTE [30].

Heparin-induced thrombocytopenia (HIT), an autoimmune reaction to heparin, occurs in approximately $5 \%$ of patients receiving unfractionated heparin [29]. These patients show hypercoagulability due to the presence of antibodies against factor 4, resulting in VTE in approximately $50 \%$ of patients with HIT who do not receive immediate treatment [29]. There have been rare cases of extensive skin necrosis associated with the use of low molecular weight heparin, such as enoxaparin, in patients who present inherited thrombophilia [33].

\section{Nephrotic syndrome}

Patients with nephrotic syndrome have a 10 to $40 \%$ risk of thrombosis (arterial and venous) [29]. Pathogenesis of VTE in this condition seems to stem from urinary loss of natural anticoagulants [29].

\section{Inflammatory bowel disease (IBD)}

Crohn's disease and ulcerative colitis are associated with an increase in the risk for VTE [34]. In a retrospective study, the risk of VTE in patients with IBD was three times greater than in those without IBD [34]. Bernstein et al. [35] concluded that patients with IBD have a greater risk of cerebral arterial thromboembolic disease [35].

\section{Resistance to activated protein C (RAPC)}

RAPC in the absence of the mutation in FVL is an independent risk factor for VTE [34]. Acquired causes of RAPC include pregnancy, use of HC, elevated F VIII, elevated factor II, and antiphospholipid antibodies [34].

\section{Transitory risk factors}

Trauma, surgery, long trips, immobilization, and installation of a central venous catheter are considered to be transitory risk factors for VTE [33]. For long trips, the duration of the trip is the key risk determining factor [34].

\section{Cryoglobulinemia}

Cryoglobulinemia is a condition due the presence of cryoglobulins. Cryoglobulins consist of a group of proteins (especially immunoglobulins), that precipitate at temperatures bellow $37^{\circ} \mathrm{C}$ and resolubilize after that the blood is heated above $37^{\circ} \mathrm{C}$ [42]. Cryoblobulins cause disease through two elementary mechanisms: hyperviscosity and/or immune complex deposition inducing complement fixation and vascular inflammation. When vasculitis is present, the condition is named as cryoglobulinemic vasculitis [42]. The Brouquet's classification is based in groups of different types of cryoglobulinemia where the immunoglobulin clonality is grouped into three categories: (i) Type I, $10 \%$ to $15 \%$ of cases (pure monoclonal immunoglobulin, and often related with B-cell-proliferative diseases, related to IgG or IgM, and eventually IgA. Malignancies including Waldenström macroglogulinemia and multiple myeloma are the most common associations); (ii) Type II, de most common form of cryoglobulinemia (polyclonal IgG combined to a monoclonal IgM directed against to polyclonal IgG, giving a frequent association with positive Rheumatoid Factor. Associated with hepatitis $\mathrm{C}$ virus infection in $80 \%$ to $98 \%$ of cases, and less frequent associated to hepatitis B virus and HIV); and (iii) Type III (polyclonal IgG with a polyclonal IgM and Rheumatoid Factor directed to polyclonal IgG. Often this type is associated to background of autoimmune diseases, including lupus or
Sjögren diseases, but eventually it can be secondary to hepatitis $\mathrm{C}$ virus or lymphoproliferative diseases) [42].

The dermatological findings associated to type I cryoglobulinemia include generally complications related to hypervicosity, whereas in mixed cryoblobulinemia the inflammatory conditions are more frequent and induces vasculitis [42]. Purpuric macules and papules on the lower extremities are present in almost patients with symptomatic cryoglobulinemia [42]. In type I cutaneous infarction, extensive ulcers, livedo racemosa, acrocyanosis and cold urticaria are usual. In mixed cryoglobulinemia, cutaneous lesions of palpable purpura or non palpable purpura are more frequent, as well as painful non-healing ulcers, especially in lower limbs [42].

\section{Dermatological manifestations associated with thrombophilia}

By favoring the formation of intravascular thrombi, thrombophilia can provoke or contribute to the development of skin necrosis [1]. With the exception of fulminating neonatal purpura, there is no clinical pathognomic manifestation of thrombophilia. There are various diseases of dermatological interest that lead one to suspect the existence of hypercoagulation, such as extensive skin necroses, fulminating post-infective or septic purpura, necrotizing cellulites, antiphospholipid syndrome, skin necrosis due to oral anticoagulants or the use of low molecular weight heparins, ulcers of the lower members, and livedoid vasculopathy [1]

In the various conditions cited above, cutaneous alterations can constitute the first manifestation of a thrombotic episode. We will discuss some dermatological conditions in detail below.

\section{Livedoid vasculopathy}

Milian's white atrophy (MWA) is the cutaneous manifestation of various diseases that lead to non-inflammatory thrombosis of the dermal vessels, leaving residual stellar porcelain-like white scars, frequently due to livedoid vasculopathy (LV), a multigenic and multifactorial disease [43-49]. Generally, the three principal factors that predispose one to thrombosis are endothelial injury, alterations in blood flow, and blood alterations leading to hypercoagulability [43].

In 1999, Criado et al. [50] observed an association between livedoid vasculopathy refractory and conventional first-line treatment with pentoxifylline and acetylsalicylic acid, the investigation of which verified the presence of anticardiolipin antibodies IgM and IgG [50].

Jorge et al. [43] identified thrombophilia of genetic and acquired origins in patients with LV in $44 \%$ of the 9 patients from this case series [47,48]. Recently, Hairston et al. [47] found abnormalities of thrombophilia in $44.1 \%$ of 29 patients evaluated.

\section{Warfarin-induced cutaneous necrosis}

Skin necrosis associated with or induced by coumarin is a rare side effect and is estimated to occur in only 0.01 to $1 \%$ of patients who use these drugs [36]. Failure to recognize and treat this condition early can lead to death [36].

The process is preceded by paresthesia and erythema with borders that are generally poorly defined [36]. The lesions become painful, well localized and ecchymotic [36]. Dermal and subcutaneous edema produces the appearance of an orange peel [36]. Within the first 24 hours, hemorrhagic boils appear within the lesions, which is a sign of irreversible skin damage [36]. The eschar eventually comes off, 
revealing the damage [35]. This condition generally occurs in middleaged obese women being treated for deep venous thrombosis or pulmonary embolism [36]. The first symptoms appear 1 to 10 days after beginning treatment with warfarin [36].

Histopathology analyses reveal damage to the microvasculature with fibrin thrombi in the post-capillary venules and small veins and diffuse but non-specific necrosis of the dermis and subcutaneous tissues [36,52-57].

The determining factors for developing warfarin-related necrosis are still unknown [36].

This condition can be prevented by progressively increasing the doses of warfarin over a longer period of time in patients who are considered to be at risk for warfarin-induced cutaneous necrosis (middle-aged women who begin treatment for thromboembolic disease) [36]. High doses of warfarin should be avoided [36]. Whether treatment with warfarin is stopped or continued does not alter the progression of the eschar [36]. After termination of warfarin, anticoagulation can be achieved with the use of intravenous heparin, especially low molecular weight heparin, until the necrotic lesion has been resolved [36].

\section{Cutaneous necrosis due to heparin}

The use of intravenous or subcutaneous heparin can also give rise to skin necrosis that is clinically and histopathologically similar to warfarin-induced necrosis $[33,36,58]$.

\section{Ulcers of the lower limbs}

In recent years, various studies have described the occurrence of thrombophilias in patients with leg ulcers $[47,59,60]$, which can be explained by two distinct mechanisms [1]:

(i) indirect form: hypercoagulability provokes a deep venous thrombosis, which in turn leads to a post-thrombotic syndrome, which is the principal known risk factor for the appearance of chronic venous ulcers [60]

(ii) direct form: thrombophilia triggers the formation of thrombi within small vessels in the dermis, which leads to the formation of ulceration, which becomes a chronic ulcer [1]

The occurrence and exact etiopathogenic role of thrombophilias in the origin of ulcers of the lower limbs remains to be established.

\section{Retiform purpura (RP)}

$\mathrm{RP}$ is an uncommon form of purpura that occurs in a livedoid, reticulated, or arcuate pattern, with geographic shapes that morphologically reflect the occlusion of the dermal and subcutaneous vasculature [40]. Blume \& Miller [63] recently reported a case of a patient with metastatic prostate cancer treated over 4 weeks with gefitinib who developed extensive livedo reticularis that evolved into $\mathrm{RP}$ with areas of necrosis on the trunk and limbs, thus adding one more condition related to RP.

\section{Who should be investigated for inherited or acquired risk factors for thrombophilia?}

In recommending which patients should have laboratory tests done to investigate the presence of thrombophilia risk factors, it should be emphasized that (i) there are different symptoms for recommendations of testing for thrombophilia and a limited consensus on these symptoms [29] and (ii) the recommendations, unfortunately, never take dermatological findings into primary consideration in symptoms for examinations, perhaps partly due to the lack of relevant studies involving the dermatological community.

For inherited thrombophilia, some authors consider the symptoms listed in Table 3 [24,65-67]. However, testing for acquired thrombophilia should be considered for every patient who does not fulfill the criteria but has had a first episode of deep venous thrombosis [29].

Another aspect to be considered is if the relatives of patients in whom a genetic thrombophilia has been discovered should be examined [29]. Inherited thrombophilias are transmitted by dominant autosomal inheritance; however, these genetic mutations are generally highly variable in clinical expressivity, and not all patients with inherited thrombophilia will develop thrombosis [68]. The utility of these tests in asymptomatic relatives is still controversial, but some authors contend that such exams may benefit selected adult individuals, given that the results may affect decisions regarding the use of prophylactic anticoagulation in situations of known risk for VTE, including trips, use of hormonal contraceptives, or surgery [29].

\section{What dermatological situations should lead to suspi- cion of thrombophilia?}

The following criteria can be useful in deciding whether to carry out investigative studies for thrombophilia: [1]

\section{Clinical criteria:}

(i) Presence of atypical ulcers with torpid evolution and resistance to conventional treatments in young people and in patients for whom

Table 3. Laboratory investigation for patients potentially suffering from thrombophilia (the exams are listed in order of most relevance for patients with thrombophilia's suspection under italic letters) Examine resistance to activated protein C (RAPC) by coagulation, which dilutes the plasma of the patient with plasma deficient in factor Vor genetic examination (PCR) for Factor V Leiden Confirm positive results in coagulation exams for RAPC with genetic examinations (PCR) Genetic test (PCR) for mutation of prothrombin (G20210A)

Functional antithrombin test (heparin co-factor)

Functional protein C test

Functional protein $S$ test combined with immunological assay for total and free protein $S$

Coagulation tests to study lupus anticoagulant and ELISA for anticardiolipin antibodies (ACA), IgM/IgG and anti- $\beta_{2}$-glycoprotein I

Measure total plasma levels of homocysteine while fasting

Dosage of cryoprecipitates (cryoglobulins, cryoagglutinins and cryofibrinogen)

Serum levels of lipoprotein(a)

Serum levels of Factor VIII, Factor IX and Factor XI

Serum levels of tissue Plasminogen activator (tPA) and Plasminogen Activactor Inhibitor (PAI)

Adapted from Bauer [64]. 
other etiologies have been carefully ruled out.

(ii) Presence of family history or persons with thromboembolic episodes, especially when recurrent, in unusual locations or without known triggering factors, as in the case of multiple abortions.

(iii) Presence of livedoid vasculopathy.

\section{Histopathological criteria:}

Presence of thrombi occluding small vessels of the middle and deep dermis without true vasculitis or with minimal concomitant inflammation.

\section{Laboratory criteria:}

Although less sensitive and specific than other information, the inexplicable prolonged duration of partially activated thromboplastin indicates thrombophilia.

\section{Which exams should be requested?}

The exams listed in table 4 are recommended for patients considered likely to present thrombophilia [65].

When subsidiary exams for thrombophilia are done, we should recall that serum levels of proteins $\mathrm{C}$ and $\mathrm{S}$ as well as antithrombin III can be reduced in the acute phase of a thromboembolic event and that these findings, as well as those for lupus anticoagulant, can be altered through treatment with oral anticoagulants or low molecular weight heparins [1].

\section{When should the patient receive anticoagulants?}

Unfortunately, dermatological manifestations are not currently among the formal criteria for indications for anticoagulation. Only for livedoid vasculopathy is there a case series that uses anticoagulants (grade $\mathrm{C}$ recommendation).

Table 4. Recommendations for investigation of inherited thrombophilia.

Idiopathic thrombosis at an age equal to or less than 50 years*

History of recurring thromboses

Unusual localization of the thrombosis (mesenteric, splenic, portal, liver, cerebral)

First-degree relatives with thrombosis, particularly patients affected by thrombosis before 50 years of age

Thrombotic event during gestation

Thrombotic event during the use of hormonal contraceptives

*Study of inherited thrombophilia is recommended when a patient does not have evidence of an acquired risk factor and was $\leq 50$ when presenting with idiopathic thrombosis. Adapted from Whitlacth [29].

Table 5. Skin manifestations in Antiphospholipid Syndrome.

\begin{tabular}{|c|c|c|}
\hline Dermatological findings & Percentages $^{\mathrm{a}}$ & Percentages $^{b}$ \\
\hline Livedo reticularis/racemosa & $24.1 \%$ & $\begin{array}{c}25.5 \%(17.5 \% \text { as first } \\
\text { manifestation })\end{array}$ \\
\hline Superficial thrombophlebitis & $11.7 \%$ & $5 \%$ \\
\hline Ulcers of the leg & $5.5 \%$ & $4.5 \%$ \\
\hline Pseudovasculitis & $3.9 \%$ & $3 \%$ \\
\hline Digital gangrene & $3.3 \%$ & $7.5 \%$ \\
\hline Skin necrosis & $2.1 \%$ & $\begin{array}{l}3.5 \% \text { (localized), } 2 \% \\
\text { (extensive) }\end{array}$ \\
\hline Subungual hemorrhages & $0.7 \%$ & $5 \%$ \\
\hline Thrombocytopenic purpura & $3.5 \%$ & - \\
\hline Primary anetoderma & $2 \%$ & - \\
\hline
\end{tabular}

Legend: aseries of 1000 patients with antiphospholipid antibody syndrome, Cervera et al. [27]; 'series of 200 patients with antiphospholipid antibody syndrome, Francês et al. [28]. Adapted from Garcia-Garcia C [22].
Indefinite anticoagulation, with the objective of maintaining the INR between 2 and 3 , is recommended only in high-risk patients $[64,77]$, such as those

1. With two or more thromboses;

2. With a spontaneous thrombosis in the case of antithrombin deficiency or of antiphospholipid syndrome;

3. With a spontaneous thrombosis with fatal risk (in general, serious pulmonary, cerebral, mesenteric, or portal thromboembolism);

4. With a spontaneous episode of thrombosis in an unusual location (in general, a mesenteric or cerebral vein);

5. With a spontaneous thrombosis in the presence of more than one single genetic defect that predisposes the patient to a thromboembolic event.

\section{Conclusions}

Inherited and acquired thrombophilias can present themselves to the dermatologist. Given the potential degree of morbidity and mortality that these conditions possess, clinical acumen with respect to cutaneous findings can provide an opportunity for proper diagnosis and treatment of these conditions $[78,79]$.

\section{References}

1. Lagran ZM (2008) Las trombofilias en dermatologia. Mas Dermatol 6: 22-26. [Crossref]

2. Egeberg O (1965) inherited antithrombin deficiency causing thrombophilia. Thromb Diath Haemorrh 13: 516-530. [Crossref]

3. Garcia AA, Franco RF (2001) Trombofilias adquiridas. Medicina, Ribeirão Preto 34 258-268. [Crossref]

4. Johnson CM, Mureebe L, Silver D (2005) Hypercoagulable states: a review. Vasc Endovascular Surg 39: 123-133. [Crossref]

5. Franco RF (2001) Trombofilias hereditarias. Medicina, Ribeirão Preto 34: 248-257. [Crossref]

6. Kuhle S, Male C, Mitchell L (2003) Developmental hemostasis: pro- and anticoagulan systems during childhood. Semin Thromb Hemost 29: 329-338. [Crossref]

7. Anderson FA Jr, Wheeler HB, Goldberg RJ, Hosmer DW, Patwardhan NA, et al. (1991) A population-based perspective of the hospital incidence and case-fatality rates of deep vein thrombosis and pulmonary embolism. The Worcester DVT Study. Arch Intern Med 151: 933-938.[Crossref]

8. Nordstrom M, Lindblad B, Bergqvist D, Kjellstrom T (1992) A prospective study of the incidence of deep-vein thrombosis within a defined urban population. J Intern Med 232: 155-160. [Crossref]

9. Jordan FL, Nandorff A (1956) The familial tendency in thrombo-embolic disease. Acto Med Scand 156: 267-275. [Crossref]

10. De Stefano V, Rossi E, Paciaroni K, Leone G (2002) Screening for inherited thrombophilia: indications and therapeutic implications. Haematologica 87: 10951108. [Crossref]

11. De Stefano V, Finazzi G, Mannucci PM (1996) Inherited thrombophilia: pathogenesis, clinical syndromes, and management. Blood 87: 3531-3544. [Crossref]

12. Franco RF, Trip MD, ten Cate H, van den Ende A, Prins MH, et al. (1999) The 20210 G-->A mutation in the 3'-untranslated region of the prothrombin gene and the risk for arterial thrombotic disease. Br J Haematol 104: 50-54. [Crossref]

13. Poort SR, Rosendaal FR, Reitsma PH, Bertina RM (1996) A common genetic variation in the 3'-untranslated region of the prothrombin gene is associated with elevated plasma prothrombin levels and an increase in venous thrombosis. Blood 88: 3698-3703. [Crossref]

14. Kearon C, Crowther M, Hirsh J (2000) Management of patients with hereditary hypercoagulable disorders. Annu Rev Med 51: 169-185. [Crossref]

15. Lane DA, Mannucci PM, Bauer KA, Bertina RM, Bochkov NP, et al. (1996) Inherited thrombophilia: Part 1. Thromb Haemost 76: 651-662. [Crossref] 
16. Sagar S, Nairn D, Stamatakis JD, Maffei FH, Higgins AF, et al. (1976) Efficacy of lowdose heparin in prevention of extensive deep-vein thrombosis in patients undergoing total-hip replacement. Lancet 1: 1151-1154. [Crossref]

17. Clouse LH, Comp PC (1986) The regulation of hemostasis: the protein C system. N Engl J Med 314: 1298-1304. [Crossref]

18. van Wijnen M, Stam JG, van't Veer C, Meijers JC, Reitsma PH, et al. (1996) The interaction of protein $\mathrm{S}$ with the phospholipid surface is essential for the activated protein C-independent activity of protein S. Thromb Haemost 76: 397-403. [Crossref]

19. Gomez E, Ledford MR, Pegelow CH, Reitsma PH, Bertina RM (1994) Homozygous protein $\mathrm{S}$ deficiency due to a one base pair deletion that leads to a stop codon in exon III of the protein S gene. Thromb Haemost 71: 723-726. [Crossref]

20. Almeida JI, Coats R, Liem TK, Silver D (1998) Reduced morbidity and mortality rates of the heparin-induced thrombocytopenia syndrome. J Vasc Surg 27: 309-314. [Crossref]

21. Bertina RM, Koeleman BP, Koster T, Rosendaal FR, Dirven RJ, et al. (1994) Mutation in blood coagulation factor $\mathrm{V}$ associated with resistance to activated protein C. Nature 369: 64-67. [Crossref]

22. Garca-Garca C (2007) [Antiphospholipid antibodies and antiphospholipid syndrome: diagnosis and management]. Actas Dermosifiliogr 98: 16-23. [Crossref]

23. Gantcheva M (1998) Dermatologic aspects of antiphospholipid syndrome. Int $J$ Dermatol 37: 173-180. [Crossref]

24. Santamara JR, Badziak D, Barros MF, Mandelli FL, Cavalin LC, et al. Antiphospholipi syndrome. An Bras Dermatol 80: 225-239. [Crossref]

25. Diagenes MJ, Diagenes PC, de Morais Carneiro RM, Neto CC, Duarte FB, et al. (2004) Cutaneous manifestations associated with antiphospholipid antibodies. Int J Dermatol 43: 632-637. [Crossref]

26. Cervera R, Piette JC, Font J, Khamashta MA, Shoenfeld Y, et al. (2002) EuroPhospholipid Project Group. Antiphospholipid syndrome: clinical and immunologic manifestations and patterns of disease expression in a cohort of 1,000 patients. Arthritis Rheum 46: 1019-1027. [Crossref]

27. FrancÃ"s C, Niang S, Laffitte E, Pelletier Fl, Costedoat N, et al. (2005) Dermatologic manifestations of the antiphospholipid syndrome: two hundred consecutive cases. Arthritis Rheum 52: 1785-1793. [Crossref]

28. Kriseman YL, Nash JW, Hsu S (2007) Criteria for the diagnosis of antiphospholipid syndrome in patients presenting with dermatologic symptoms. J Am Acad Dermatol 57: 112-115. [Crossref]

29. Whitlatch NL, Ortel TL (2008) Thrombophilias: when should we test and how does it help? Semin Respir Crit Care Med 29: 25-39. [Crossref]

30. Cushman M, Kuller LH, Prentice R, Rodabough RJ, Psaty BM, et al. (2004) Estrogen plus progestin and risk of venous thrombosis. JAMA 292: 1573-1580. [Crossref]

31. Saphner T, Tormey DC, Gray R (1991) Venous and arterial thrombosis in patients who received adjuvant therapy for breast cancer. J Clin Oncol 9: 286-294. [Crossref]

32. Rajkumar SV (2005) Thalidomide therapy and deep venous thrombosis in multiple myeloma. Mayo Clin Proc 80: 1549-1551. [Crossref]

33. Nadir Y, Mazor Y, Reuven B, Sarig G, Brenner B, et al. (2006) A fatal case of enoxaparin induced skin necrosis and thrombophilia. Eur J Haematol 77: 166-168. [Crossref]

34. Bernstein CN, Blanchard JF, Houston DS, Wajda A (2001) The incidence of deep venous thrombosis and pulmonary embolism among patients with inflammatory bowel disease: a population-based cohort study. Thromb Haemost 85: 430-434. [Crossref]

35. Bernstein CN, Wajda A, Blanchard JF (2008) The incidence of arterial thromboembolic diseases in inflammatory bowel disease: a population-based study. Clin Gastroenterol Hepatol 6: 41-45. [Crossref]

36. Chan YC, Valenti D, Mansfield AO, Stansby G (2000) Warfarin induced skin necrosis Br J Surg 87: 266-272. [Crossref]

37. Clivati Brandt HR, de Lorenzo Messina MC, Belda Junior W, Costa Martins JE, Criado PR (2007) Leg ulcers associated with factor V Leiden and prothrombin G20210A and methyltetrahydrofolate reductase mutations: successful treatment with warfarin. Int $J$ Dermatol 46: 1319-1320. [Crossref]

38. Criado PR, Bernardelli IM, Rivitti EA, Sotto MN, Vilella MA, et al. (2007) Childhoodonset skin necrosis resulting from protein $\mathrm{C}$ deficiency. $J$ Eur Acad Dermatol Venereol 21: 537-539. [Crossref]
39. Lipsker D, Kara F (2008) Images in clinical medicine. Retiform purpura. $N$ Engl J Med 358: e1. [Crossref]

40. Jones A, Walling H (2007) Retiform purpura in plaques: a morphological approach to diagnosis. Clin Exp Dermatol 32: 596-602. [Crossref]

41. Kalajian AH, Turpen KB, Donovan KO, Malone JC, Callen JP (2007) Phenylephrineinduced microvascular occlusion syndrome in a patient with a heterozygous factor $\mathrm{V}$ Leiden mutation. Arch Dermatol 143: 1314-1317. [Crossref]

42. Ghetie D, Mehraban N, Sibley CH (2015) Cold hard facts of cryoglobulinemia: updates on clinical features and treatment advances. Rheum Dis Clin North Am 41: 93-108, viii-ix. [Crossref]

43. Jorge AD, Fantini BC, Rivitti EA, Benabou JE, Vasconcellos C, et al. (2007) Analise da frequencia de trombofilia em pacientes com atrofia branca de Milian. An Bras Dermatol 82: 25-33. [Crossref]

44. Davis MD, Wysokinski WE (2008) Ulcerations caused by livedoid vasculopathy associated with a prothrombotic state: Response to warfarin. J Am Acad Dermatol 58: 512-515. [Crossref]

45. Anavekar NS, Kelly R (2007) Heterozygous prothrombin gene mutation associated with livedoid vasculopathy. Australas J Dermatol 48: 120-123. [Crossref]

46. Callen JP (2006) Livedoid vasculopathy: what it is and how the patient should be evaluated and treated. Arch Dermatol 142: 1481-1482. [Crossref]

47. Hairston BR, Davis MD, Pittelkow MR, Ahmed I (2006) Livedoid vasculopathy: furthe evidence for procoagulant pathogenesis. Arch Dermatol 142: 1413-1418. [Crossref]

48. Cocuroccia B, Tonanzi T, Menaguale G, Fazio M, Girolomoni G (2002) Livedoid vasculopathy and skin ulcers in patients with inherited thrombophilia. Eur J Dermatol 12: 360-363. [Crossref]

49. Biedermann T, Flaig MJ, Sander CA (2000) Livedoid vasculopathy in a patient with factor V mutation (Leiden). J Cutan Pathol 27: 410-412. [Crossref]

50. Gilaberte Y, Coscojuela C, Lezaún A, Marigil MA (2005) Degos disease associated with protein S deficiency. Br J Dermatol 153: 666-667. [Crossref]

51. Criado PR, LavÃ'r IM, Landman G (2001) Vasculopatia Lived $\tilde{A}^{3} i d e$ associada a Anticorpos Anticardiolipina. Rev Bras ClÃn Terap 27: 195-198.

52. Gipstein RM, Coburn JW, Adams DA, Lee DB, Parsa KP, et al. (1976) Calciphylaxis in man. A syndrome of tissue necrosis and vascular calcification in 11 patients with chronic renal failure. Arch Intern Med 136: 1273-1280. [Crossref]

53. Matsumura T, Matsumoto A, Ohno M, Suzuki S, Ohta M, et al. (2006) A case of cholesterol embolism confirmed by skin biopsy and successfully treated with statins and steroids. Am J Med Sci 331: 280-283. [Crossref]

54. Rachmilewitz EA, Sacks MI, Zlotnick A (1970) Essential cryofibrinogenemia. Clinical, pathological and immunological studies. Isr J Med Sci 6: 32-43. [Crossref]

55. Dodd HJ, Sarkany I, O'Shaughnessy D (1985) Widespread cutaneous necrosis associated with the lupus anticoagulant. Clin Exp Dermatol 10: 581-586. [Crossref]

56. Rossini J, Roverano S, Graf C, Paira S (2002) Widespread cutaneous necrosis associated with antiphospholipid antibodies: report of four cases. J Clin Rheumatol 8 : 326-331. [Crossref]

57. Barrio VR, Sanfilippo AM, Malone JC, Callen JP (2004) Nonhealing ulcer secondary to factor V Leiden mutation and cryofibrinogenemia. J Am Acad Dermatol 51: S194196. [Crossref]

58. Prasad HK, Govindarajan R (2007) Heparin-induced skin necrosis associated with thrombocytopenia and acquired protein $\mathrm{C}$ and protein $\mathrm{S}$ deficiency. Am J Hematol 82: 1116-1117. [Crossref]

59. Mackenzie RK, Ludlam CA, Ruckley CV, Allan PL, Burns P, et al. (2002) The prevalence of thrombophilia in patients with chronic venous leg ulceration. J Vasc Surg 35: 718-722. [Crossref]

60. Baker WF Jr, Bick RL (1999) Treatment of hereditary and acquired thrombophilic disorders. Semin Thromb Hemost 25: 387-406. [Crossref]

61. Brandt HR, de Lorenzo Messina MC, Hirayama JT, Belda W Jr, Benabou JE, et al (2009) Prevalence of thrombophilia associated with leg ulcers. Br J Dermatol 160: 202-203. [Crossref]

62. Silveira MT, Criado PR, Valente NYS, Vasconcellos C (2004) PÃ ${ }^{\circ}$ rpura fulminante em paciente HIV positivo. An Bras Dermatol 79: S291-99.

63. Blume JE, Miller CC (2007) Livedo reticularis with retiform purpura associated with gefitinib (Iressa). Int J Dermatol 46: 1307-1308. [Crossref] 
64. Kanazawa S, Yamaguchi K, Kinoshita Y, Muramatsu M, Komiyama Y, et al. (2005) Gefitinib affects functions of platelets and blood vessels via changes in prostanoids balance. Clin Appl Thromb Hemost 11: 429-434. [Crossref]

65. Bauer KA (2001) The thrombophilias: well-defined risk factors with uncertain therapeutic implications. Ann Intern Med 135: 367-373. [Crossref]

66. Perry SL, Ortel TL (2003) Clinical and laboratory evaluation of thrombophilia. Clin Chest Med 24: 153-170. [Crossref]

67. Moll S (2006) Thrombophilias--practical implications and testing caveats. $J$ Thromb Thrombolysis 21: 7-15. [Crossref]

68. Lochhead P, Miedzybrodzka Z (2007) The essential role of genetic counseling in inherited thrombophilia. Semin Hematol 44: 126-129. [Crossref]

69. Simioni P, Tormene D, Prandoni P, Zerbinati P, Gavasso S, et al. (2002) Incidence of venous thromboembolism in asymptomatic family members who are carriers of factor V Leiden: a prospective cohort study. Blood 99: 1938-1942. [Crossref]

70. Mavragani CP, Pikazis D, Aroni K, Paikos S, Voulgarelis M (2004) Cutaneous ulcers: An unusual manifestation of inherited thrombophilia. Am J Hematol 76: 139-142. [Crossref]

71. Renner R, Simon JC (2008) Current therapeutic options of chronic leg ulcers. J Dtsch Dermatol Ges 6: 389-401. [Crossref]
72. Bradbury AW, MacKenzie RK, Burns P, Fegan C (2002) Thrombophilia and chronic venous ulceration. Eur J Vasc Endovasc Surg 24: 97-104. [Crossref]

73. Handel DW, Roenigk HH Jr, Shainoff J, Deodhar S (1975) Necrotizing vasculitis Etiologic aspects of immunology and coagulopathy. Arch Dermatol 111: 847-852. [Crossref]

74. Bednarek N, Morville P, Delebarre G, Akhavi A, Sommer C (2007) Necrotic skin lesions and cerebral infarction in the newborn: two case reports. J Child Neurol 22 354-357. [Crossref]

75. Agras PI, Ozdemir H, Baskin E, Ozbek N (2007) Recurrent vasculopathic skin lesions associated with homozygous protein C deficiency. Pediatr Dermatol 24: 57-60. [Crossref]

76. Uthman IW, Khamashta MA (2006) Livedo racemosa: a striking dermatological sign for the antiphospholipid syndrome. J Rheumatol 33: 2379-2382. [Crossref]

77. Bauer KA (2003) Management of thrombophilia. J Thromb Haemost 1: 1429-1434. [Crossref]

78. Criado PR, Rivitti EA, Vasconcellos C, Valente NYS, Martins JE (2008) ManifestaÃß̃̃ $\mu$ es cutÃ [Crossref]

79. Thornsberry LA, LoSicco KI, English JC 3rd (2013) The skin and hypercoagulable states. J Am Acad Dermatol 69: 450-462. [Crossref]

Copyright: $(02016$ Criado PR. This is an open-access article distributed under the terms of the Creative Commons Attribution License, which permits unrestricted use, distribution, and reproduction in any medium, provided the original author and source are credited. 